\title{
The impact of human and mouse differences in NOS2 gene expression on the brain's redox and immune environment
}

Michael D Hoos', Michael P Vitek², Lisa A Ridnour³, Joan Wilson², Marilyn Jansen², Angela Everhart², David A Wink ${ }^{3}$ and Carol A Colton ${ }^{2^{*}}$

\begin{abstract}
Background: Mouse models are used in the study of human disease. Despite well-known homologies, the difference in immune response between mice and humans impacts the application of data derived from mice to human disease outcomes. Nitric oxide synthase-2 (NOS2) is a key gene that displays species-specific outcomes via altered regulation of the gene promoter and via post-transcriptional mechanisms in humans that are not found in mice. The resulting levels of NO produced by activation of human NOS2 are different from the levels of NO produced by mouse Nos2. Since both tissue redox environment and immune responsiveness are regulated by the level of $\mathrm{NO}$ and its interactions, we investigated the significance of mouse and human differences on brain oxidative stress and on immune activation in HuNOS $2^{\text {tg }} / \mathrm{mNOS}^{-1-}$ mice that express the entire human NOS2 gene and that lack a functional mNos 2 compared to wild type (WT) mice that express normal mNos2.
\end{abstract}

Methods/results: Similarly to human, brain tissue from HuNOS $2^{t g} / \mathrm{mNos}^{-/-}$mice showed the presence of a NOS2 gene 3'UTR binding site. We also identified miRNA-939, the binding partner for this site, in mouse brain lysates and further demonstrated reduced levels of nitric oxide (NO) typical of the human immune response on injection with lipopolysaccharide (LPS). HuNOS $2^{t g} / \mathrm{mNos}^{-1-}$ brain samples were probed for characteristic differences in redox and immune gene profiles compared to WT mice using gene arrays. Selected genes were also compared against $\mathrm{mNos}^{-{ }^{--}}$brain lysates. Reconstitution of the human NOS2 gene significantly altered genes that encode multiple anti-oxidant proteins, oxidases, DNA repair, mitochondrial proteins and redox regulated immune proteins. Expression levels of typical pro-inflammatory, anti-inflammatory and chemokine genes were not significantly different with the exception of increased TNFa and C $\mathrm{cr} 1 \mathrm{mRNA}$ expression in the HuNOS2 $2^{t g} / \mathrm{mNOS}^{-/-}$mice compared to WT or $\mathrm{mNos}^{-/-}$mice.

Conclusions: $\mathrm{NO}$ is a principle factor in establishing the tissue redox environment and changes in NO levels impact oxidative stress and immunity, both of which are primary characteristics of neurodegenerative diseases. The HuNOS $2^{\text {tg }} / \mathrm{mNOS}^{-/-}$mice provide a potentially useful mechanism to address critical species- specific immune differences that can impact the study of human diseases.

Keywords: NOS2, Mouse models, Neurodegeneration, Redox, Inflammation, Nitric oxide

\footnotetext{
* Correspondence: Carol.Colton @duke.edu

${ }^{2}$ Department of Neurology, Duke University Medical Center, Durham, NC 27710, USA

Full list of author information is available at the end of the article
}

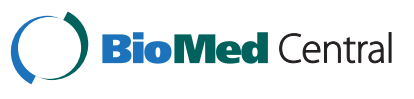

(c) 2014 Hoos et al.; licensee BioMed Central Ltd. This is an Open Access article distributed under the terms of the Creative Commons Attribution License (http://creativecommons.org/licenses/by/4.0), which permits unrestricted use, distribution, and reproduction in any medium, provided the original work is properly credited. The Creative Commons Public Domain Dedication waiver (http://creativecommons.org/publicdomain/zero/1.0/) applies to the data made available in this article, unless otherwise stated. 


\section{Background}

The past five years have proven to be disappointing and frustrating to pre-clinical scientists in the Alzheimer's field. Multiple therapeutics that worked to reduce amyloid mediated pathology in established mouse models of Alzheimer's disease (AD) have not proven to be useful in humans with $\mathrm{AD}$ and, in some cases, have made the disease outcomes worse [1-4]. The results of these and other clinical trials have now driven the search for a better understanding of $\mathrm{AD}$ disease mechanisms and emphasize the pressing need for re-evaluation of research directions in the field. Recently, a critical avenue of research relevant to neurodegeneration has been a subject of renewed interest. Although immune changes in AD have been known for many years, the importance of an immune response to the disease process was unclear. This was despite convincing evidence from Caleb Finch [5], W. Sue Griffin [6,7], Piet Eikenlenboom [8], Patrick and Edith McGeer [9,10] and others who showed that immune responses were observed as an early and key pathological characteristic of humans with AD. Data from genome-wide association studies (GWAS) have now firmly established that genes involved in the immune response are central to the risk for development of late onset Alzheimer's disease [11-13]. These genes encode proteins that include apolipoprotein $\mathrm{E}$ (APOE) that serves as a global immune regulator [14], complement receptor $1(\mathrm{CR} 1)$ that may mediate $\mathrm{A} \beta$ clearance from the brain [15], CD33 (Siglec11) that when expressed on microglia becomes neuroprotective [16] and TREM2 with its downstream target TYROBP (DAP12) that regulates multiple microglial functional pathways $[17,18]$. The immune response in AD is clearly a critical event in the disease process. Zhang et al. [17] using an integrated network analysis of late onset AD-associated genes showed that immune/microglia gene networks demonstrated the strongest degree of disease association and the highest correlation to $\mathrm{AD}$ neuropathology compared to other gene subsets. Despite these exciting findings, we still don't understand how immune cells such as microglia are involved in the initiation or progression of disease, if and when their involvement changes with time or even what type of response is generated by microglia (or other immune cells) at different stages of AD.

Seok et al. [19] have re-enforced an additional dimension of complexity that impacts our methodologies we use to understand how the brain's immune response is involved in neurodegenerative diseases such as AD. In their controversial study, Seok and colleagues compared the genomic responses of mice and humans during an acute immune response resulting from endotoxemia, burns or trauma. Their study demonstrated that correlations between mouse and human immune signaling pathways were poor for these acute illnesses and at least for pathways that are commonly initiated by lipopolysaccharide
(LPS), mouse gene changes were not predictive of human gene changes for a similar disease initiation process. More recently, this interpretation has been challenged by Takao and Miyakawa [20]. Regardless, it is generally agreed that not only are disease-based changes in immunity a challenging issue, but also the models used to study human immune responses during disease should be carefully considered.

The recognition that mouse immune processes are not the same as human immune processes is clearly not new. Mestas and Hughes in 2004 [21] defined a number of differences in both innate and adaptive immune characteristics between rodents and man. These differences include Fc receptor subtypes, the action of IFN $\alpha$ on Th1 cells and the involvement of the Th2 response in clearance of parasites. In 1995 our lab showed that cultured microglia and macrophages from humans showed limited nitric oxide (NO) production in response to immune stimuli that were commonly used on mouse cells in culture such as LPS or polyinosinic:polycytidylic acid (PIC) alone or in combination with cytokines such as interferon- $\gamma$ (IFN $\gamma$ ) or interleukin-1 $\beta$ [22,23]. Microglia cultured from rodent brains, however, are well known to produce robust levels of NO when stimulated with the same induction agents. $\mathrm{NO}$ is the product of the inducible iNOS protein that is encoded by the NOS 2 gene and serves defensive and regulatory roles in an immune response. Multiple other labs have observed similar differences between NO production in mouse and in human cells and a vigorous discussion on the molecular mechanisms underlying these differences has ensued over the intervening years [24-28]. An elegant study by Guo et al. [29] demonstrated a reasonable explanation for these differences. Guo, Geller and colleagues found binding sites for a microRNA (miRNA-939) in the 3'untranslated region (UTR) of the human NOS2 gene. When these sites are bound to miRNA-939, a posttranscriptional repression of iNOS protein expression is initiated and NO production was thereby reduced. While this may not be the sole mechanism for differences between human and rodent NO production and differences in promoter regulatory activity also exist [25,30-32], miRNA-mediated silencing may account for a large part of the inability to readily stimulate and measure $\mathrm{NO}$ in human macrophages and microglia.

Despite problems with species-specific responses, it is equally clear that mouse models of disease facilitate the mechanistic study of cellular and integrated systems at multiple stages of a disease process. Animal models will remain a valuable tool to understand human disease. However, the translatability of these data derived from mice to human is ultimately a question. Furthermore, the lack of models that more closely resemble the human immune environment remains a core problem. In addition to differences in immune regulatory events [19,33,34], 
these problems include our lack of knowledge on regulation of the cell and tissue redox environment that also impacts immunity $[34,35]$.

One way to address these issues is to "humanize" mouse models by replacing mouse genes with corresponding human genes. There are currently many examples of this type of approach including multiple models of neurodegenerative disease where a mutated gene is added in addition to the mouse gene (for example, the APPsw-Tg2576 mice; [36] or where the human gene replaces a large part of the mouse gene with or without replacing the promoter region of the gene (Apoe4 targeted replacement mice, [37]). Similar methodologies have been used for immune genes. The choice of which mouse gene to alter depends on the disease process.

We have developed mouse models of AD that express mutated human amyloid precursor protein $(A P P)$ and also demonstrate human-like NO production when immune stimulated. Our scientific rationale for this model was based on the interrelationship between inflammation, oxidative stress and neurodegeneration $[34,38]$. NO serves as a nodal point between inflammation and oxidative stress, and when altered, results not only in a changed brain redox environment $[34,35]$, but also in altered immune regulation, both of which impact human disease $[33,34]$. The types of interactions and their products are now well described in excellent reviews and will not be discussed here [39-43]. However, it is clear that both superoxide anion through oxidative events and NO through both direct and indirect reactions regulate multiple proteins and cellular pathways in a precise manner. These pathways dictate immune regulation and immune defense [34]. Because the direct and indirect reactions of $\mathrm{NO}$ are dependent on the available concentration of $\mathrm{NO}$, the consumption of $\mathrm{NO}$, for example by combination with superoxide anion, significantly impacts the redox environment of the tissue and alters multiple NO-dependent pathways [42-44]. By shifting the inherent NO level during an immune response, the outcome is likely to provide a unique subset of regulatory and defensive events that are tailored to the individual species. Evolution has made this shift for humans and rodents and has imposed a difference in NOS2 regulation between these species.

To better understand the importance of mouse and human Nos2 differences, we have generated a mouse model that expresses the entire human NOS2 gene on a mouse Nos2 knockout background [45]. This new mouse strain has gene regulatory sites that, similar to the human NOS2 gene, are associated with reduced NO production. Here, we show characteristic redox gene differences between mice expressing a normal mNos 2 gene and mice expressing only the huNOS2 gene. We also discuss the potential impact of these gene differences on tissue redox balance and immunity.

\section{Results}

HuNOS $2^{\text {tg }} / \mathrm{mNos}^{-/-}$mice show $3^{\prime}$ UTR binding sites, miRNA-939 homolog and reduced NO production in vivo Guo et al. [31] have shown that miRNA-939 binds to sites in the 3'UTR region of the human NOS2 gene, thereby altering the translation of iNOS protein and reducing NO production. To determine if the human NOS2 gene in $\mathrm{HuNOS2}^{\mathrm{tg}} / \mathrm{mNos}^{-/-}$mice expressed the appropriate 3' UTR binding sites we PCR amplified the miRNA-939 binding region from DNA isolated from $\mathrm{HuNOS2}^{\text {tg }}$ / $m N o s 2^{-/-}$brain tissue. Figure $1 \mathrm{~A}$ shows the results of a typical genotyping assay for 7 individual $\mathrm{HuNOS}^{\mathrm{tg}}$ / $m N o s 2^{-1-}$ mice and corresponding WT mice. The upper band found in mice expressing the HuNOS2 gene corresponds to a region of the mNos 2 gene, which has remained intact in the $m \mathrm{Nos}^{-/-}$strain despite the disruption to the $m N o s 2$ gene. The lower band corresponds to a 185 bp product containing the 3'UTR miRNA-939 binding region of huNOS2 gene.

Having demonstrated that $\mathrm{HuNOS2^{tg }} / \mathrm{mNos}^{-{ }^{--}}$mice express the 3'UTR binding site that is characteristic of the human NOS2 gene, we then used RT-PCR to detect the presence of a miRNA-939 homolog in brain and liver lysates from lipopolysaccharide (LPS)- treated $\mathrm{HuNOS}^{t g}$ / $m N o s 2^{-/-}$mice. LPS diluted into saline was injected intravenously (iv) to induce an immune response that includes induction of the NOS2 gene and immune-related cytokines. Saline-injected mice were used as untreated controls. At 7 hrs after injection, we assayed brain samples for miRNA-939 and used small nucleolar RNA-202 (snoRNA-202) as an endogenous control for microRNAs. Figure $1 \mathrm{~B}$ presents results from a typical PCR cycling reaction and demonstrates the presence of miRNA-939 in HuNOS2 ${ }^{\operatorname{tg}} / \mathrm{mNos}^{-/-}$brain. We also examined the effect of LPS treatment on the level of miRNA-939 homolog in our mice. Figure $1 \mathrm{C}$ shows the average fold change ( \pm sem) in miRNA-939 in brain and liver samples after stimulation with LPS. A similar LPS-mediated increase in miRNA939 levels was shown by Guo et al. [29] for human hepatocytes in culture and in liver lysates from WT mice injected with LPS or a cytokine mix.

Our previously published studies using LPS or cytokinestimulated primary cultures of peritoneal macrophages

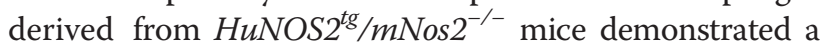
significant decrease in the conversion of $\left[\mathrm{H}^{3}\right]$ arginine to $\left[\mathrm{H}^{3}\right]$ citrulline [45], indicating reduced iNOS enzymatic activity compared to WT mice. Human and mouse NOS2 have similar specific activity suggesting that changed activity is regulated via cellular processes [46]. In addition, we showed that NO production in immune stimulated cultured peritoneal macrophages was also significantly decreased in $\mathrm{HuNOS2}^{\mathrm{tg}} / \mathrm{mNos}^{-1-}$ mice compared to similarly treated WT mice. To show that in vivo NO production was also altered we measured total nitrite 


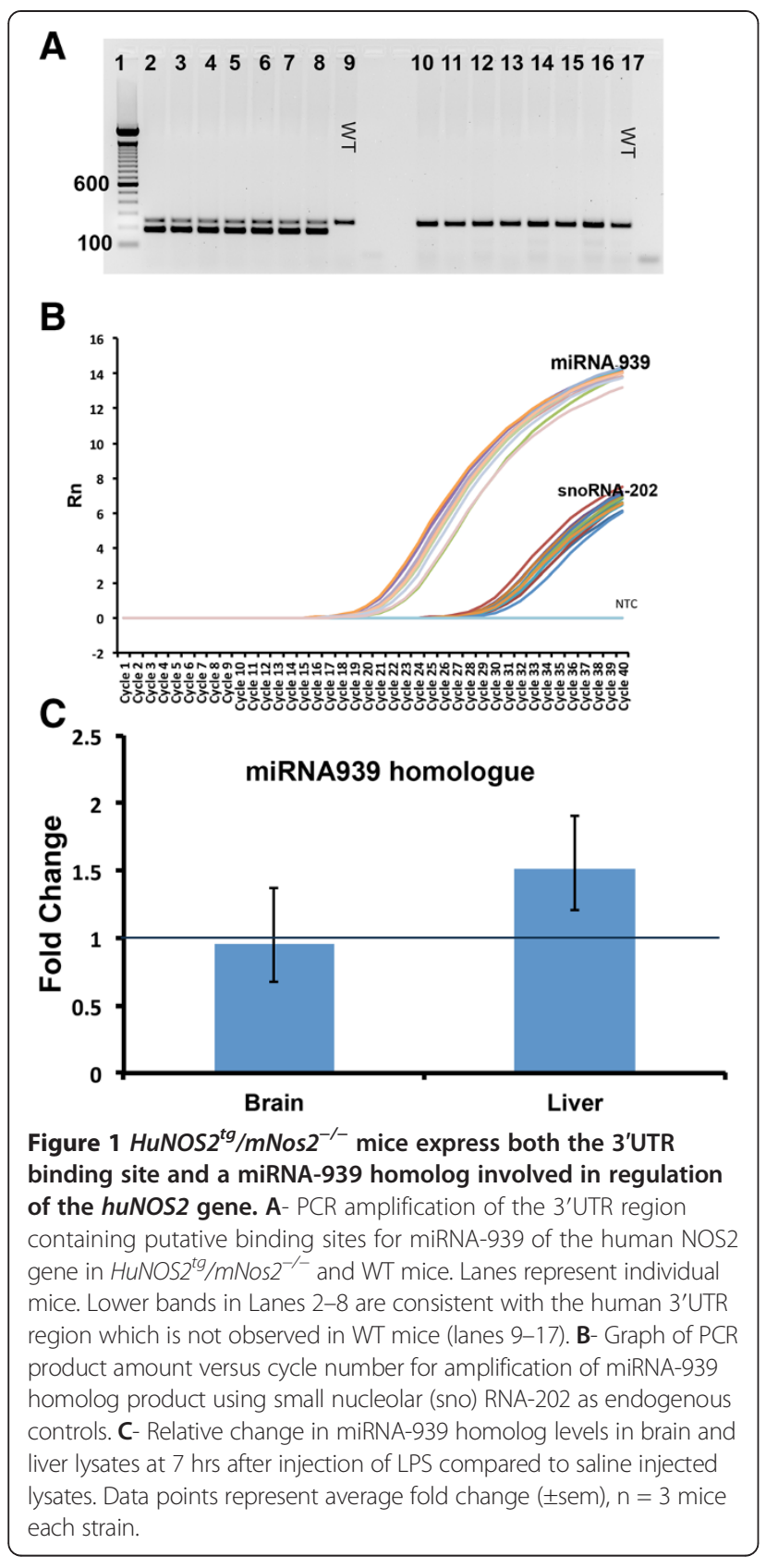

plus nitrate $(\mathrm{NOx})$ levels in whole brain lysates in $\mathrm{HuNOS} 2^{t g} / \mathrm{mNos} 2^{-/-}$mice compared to similarly treated $m N o s 2^{-/-}$and WT mice. All mice (36-40 weeks of age) were intravenously (iv) injected with either $10 \mathrm{mg} / \mathrm{kg}$ of LPS or saline $(0.9 \% \mathrm{NaCl})$ via the tail vein and tissues were collected at either 7,18 or 24 hrs post injection. Figure 2A show mRNA levels for LPS-treated mice compared to untreated (saline-injected) conditions for both WT and $H u N O S 2^{t g} / m N o s 2^{-/-}$mice brain lysates. As predicted, mRNA increased in both strains on LPS stimulation, however, levels of expression were lower in mice expressing the huNOS2 gene. We next compared nitrite and nitrate (NOx) levels in brain (Figure 2B) and liver (Figure 2C) lysates derived from LPS-injected or salineinjected WT mice to the levels of NOx found in lysates from $m N o s 2^{-/-}$and $H u N O S 2^{t g} / m N o s 2^{-/-}$mice. As predicted, WT mice demonstrated a significantly increased level of NOx in both brain and liver tissue lysates with time after immune stimulation. However, neither $m N o s 2^{-/-}$knockout mice nor $H u N O S 2^{t g} / m N o s 2^{-/-}$ mice showed a measurable in vivo response to treatment with LPS when compared to WT-Nos2 sufficient mice.

\section{HuNOS2 $2^{t g} / m$ Nos $2^{-/-}$mice show a unique redox gene profile}

To better understand how reconstitution of the human NOS2 gene in a $m N o s 2^{-/-}$knockout background impacts the redox and immune profile compared to WT mice that normally express $m$ Nos 2 and high levels of NO, we performed a directed gene array analysis. For this experiment RNA was extracted from brain lysates previously prepared from the WT and HuNOS $2^{t g} / m N o s 2^{-1-}$ mice injected with either LPS (10 mg/kg) or saline. Quantitative RT-PCR was performed on the cDNA using a custom TaqMan Gene Expression Assay plate (Life Technologies). The array was designed to evaluate a defined mixture of redox and immune genes and three mice for each treatment group at each time point were assessed. All CT values were normalized to endogenous levels of 18sRNA and average fold change values (RQ) were determined by $2^{(-\Delta \Delta C t)}$ method using either WT saline- injected or $H u N O S 2^{t g} / m N o s 2^{-/-}$saline- injected as the comparator [47]. The resultant RQ values for LPS-treated HuNOS2 ${ }^{t g}$ / $m N o s 2^{-1-}$ mice (here abbreviated $\mathrm{HN}$ ) and WT mice samples were then compared at 7 and 24 hrs post-LPS injection. To better visualize the changes due to LPS treatment for each mouse strain and at each time point, a heat map was prepared using these ratios (Figure 3). Ratio values were linearized by $\log 2$ conversion, then subjected to conditional formatting whereby $\log 2(\mathrm{RQ})$ values less than 0 were colored red (decreased expression) and Log2(RQ) values greater than 0 were colored green (increased expression) according to the scale in Figure 3. Asterisks denote a statistically significant change due to LPS treatment with respect to control (saline-injected) mice. In addition, we compared the fold-change in expression levels in LPS treated $\mathrm{HuNOS} 2^{t g} / \mathrm{mNos} 2^{-/-}$mice for each gene to the corresponding fold-change found in WT mice. Statistically significant changes for these data are shown only for the 24 hrs treatment point and are labeled on the heat map with a delta $(\Delta)$ sign. Genes are also grouped according to their known function.

LPS stimulation differentially altered the expression of redox related genes in both a time and gene specific manner in the HuNOS $2^{t g} / m N o s 2^{-/-}$mice compared to WT mice. For example, as shown in the heat map, DNA 


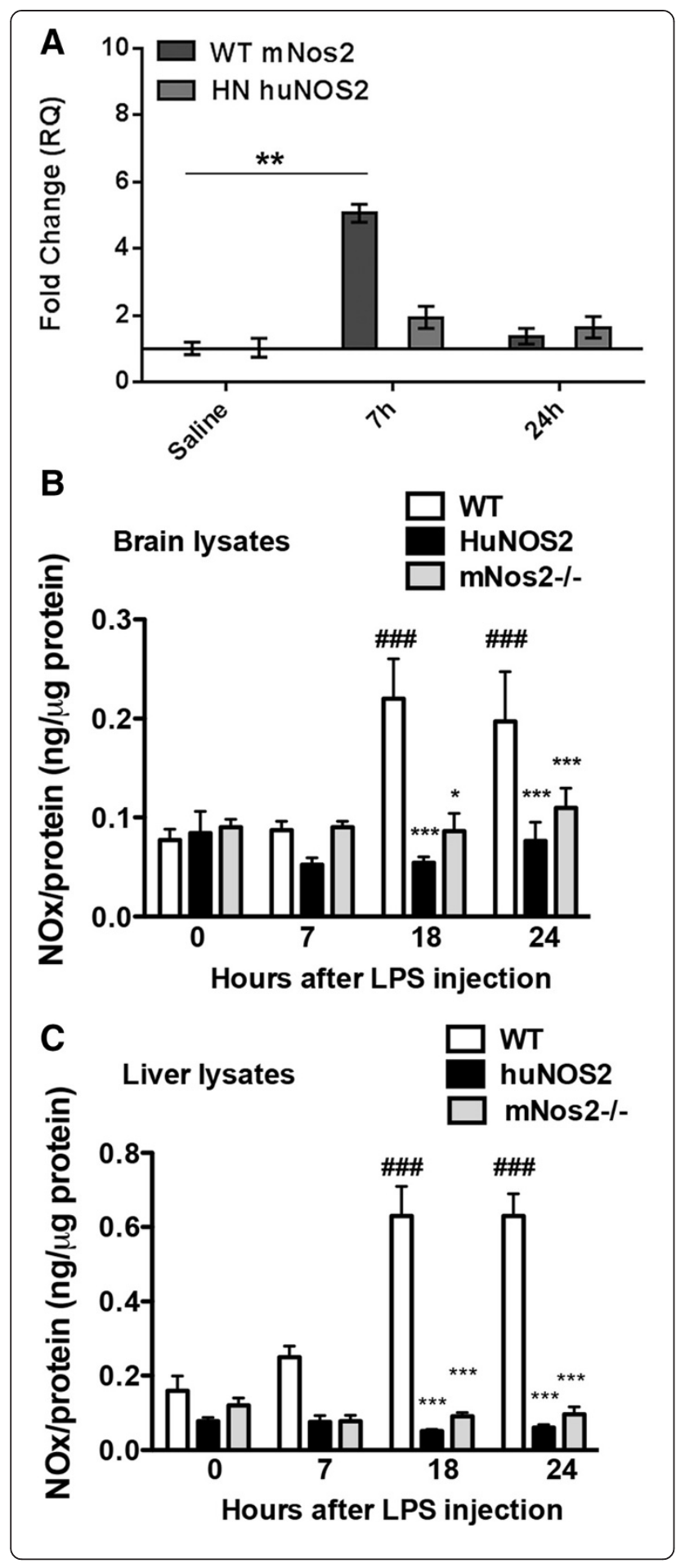

Figure 2 LPS-stimulated mRNA and NOx production in HuNOS $2^{t g} / \mathrm{mNos}^{-/-}$mice. A. Comparison of the fold changes in NOS2 mRNA levels for HuNOS2 and mNos2 (WT) mice. Brain lysates were prepared from saline injected and LPS injected WT and HuNOS $2^{\text {tg }} / \mathrm{mNos}^{-/-}$mice at 7 and $24 \mathrm{hrs}$. Average fold changes ( \pm sem) for LPS-treatment were determined using the average saline-injected value as comparator. $n=3$ mice/group. ${ }^{* *}=p<0.01$ using the unpaired student's $t$ test with significance set at $p<.0 .05$. B. Brain lysate levels of nitrite and nitrate (NOx) were measured in HuNOS $2^{\text {tg }} / \mathrm{mNos}^{2--}$, mNos2 $2^{-1-}$ and WT mice at 7, 18 and $24 \mathrm{hrs}$.

Saline- injected mice from each strain served as the 0 hrs time point. Average NOx values (ng/ug protein \pm sem) are shown where $n=6-9$ mice/strain per time point. Significance with time within strain was determined using one-way ANOVA while statistical significance across genotypes was determined using two-way ANOVA (GraphPad Software, San Diego (A). Significance was set at $p \leq 0.05$. ${ }^{*} p<0.05$; ${ }^{* * *} p<0.001$ for comparisons across strains; \#\#\# <0.001 for comparisons within strain. C. Analysis of NOx in liver lysates from the same mice as above and under the same conditions. ${ }^{* *} p<0.001$ for comparisons across strains; \#\#\# <0.001 for comparisons within strain.

repair genes that are critical to reducing oxidative DNA damage such as Excision Repair Cross Complementation 2 (Ercc2) that encodes the XPD protein and Ercc6 that encodes the Cockayne syndrome b (CSB) protein show no significant gene induction in $\mathrm{HuNOS} 2^{t g} / \mathrm{mNos}^{-/-}$ mice at 7 hrs post-LPS injection. By 24 hrs, however, expression of these genes in response to LPS-injection in $H u N O S 2^{t g} / m N o s 2^{-/-}$mice was observed, indicating a different time to response in $\mathrm{HuNOS} 2^{t g} / \mathrm{mNos}^{-{ }^{--}}$mice vs WT mice. Checkpoint homolog 1 (Chek1) and the transcription factor $\mathrm{p} 53$ follow a similar pattern. The significance of this delayed repair response to LPS in $H u N O S 2^{t g} / m N o s 2^{-/-}$mice is not clear, but it suggests that NO levels affect the early phases of the innate immune process in a species-specific manner. Similarly, we find that anti-oxidant and oxidant genes show a significantly higher or lower expression level in LPS-treated $H u N O S 2^{t g} / m N o s 2^{-/-}$mice at 24 hrs post-injection compared to similarly treated WT mice. Selected genes are also shown in Table 1. As predicted from the role of NO as a regulator of oxidant/antioxidant balance, HuNOS2 $2^{t g}$ / $m N o s 2^{-/-}$mice show decreased expression (WT $>\mathrm{HN}$ ) of many antioxidant genes (peroxiredoxins, glutathione reductase $(G s r)$, catalase $(C a t))$ concomitant with increased expression of genes $(\mathrm{HN}>\mathrm{WT})$ associated with oxidative pathways such as Cyba (the b subunit of the NADPH oxidase), Lpo (lactoperoxidase) and eosinophil peroxidase $(E p x)$ compared to WT mice. This altered expression pattern is indicative of a shift of the response at $24 \mathrm{hrs}$ potentially to a more "oxidative" environment that is regulated by NO flux. Again, how this exactly impacts the disease process remains unknown but it is likely to dictate a different overall redox microenvironment of affected cells.

To better understand how varying $\mathrm{NO}$ levels in vivo might alter LPS-stimulated gene expression, we further 


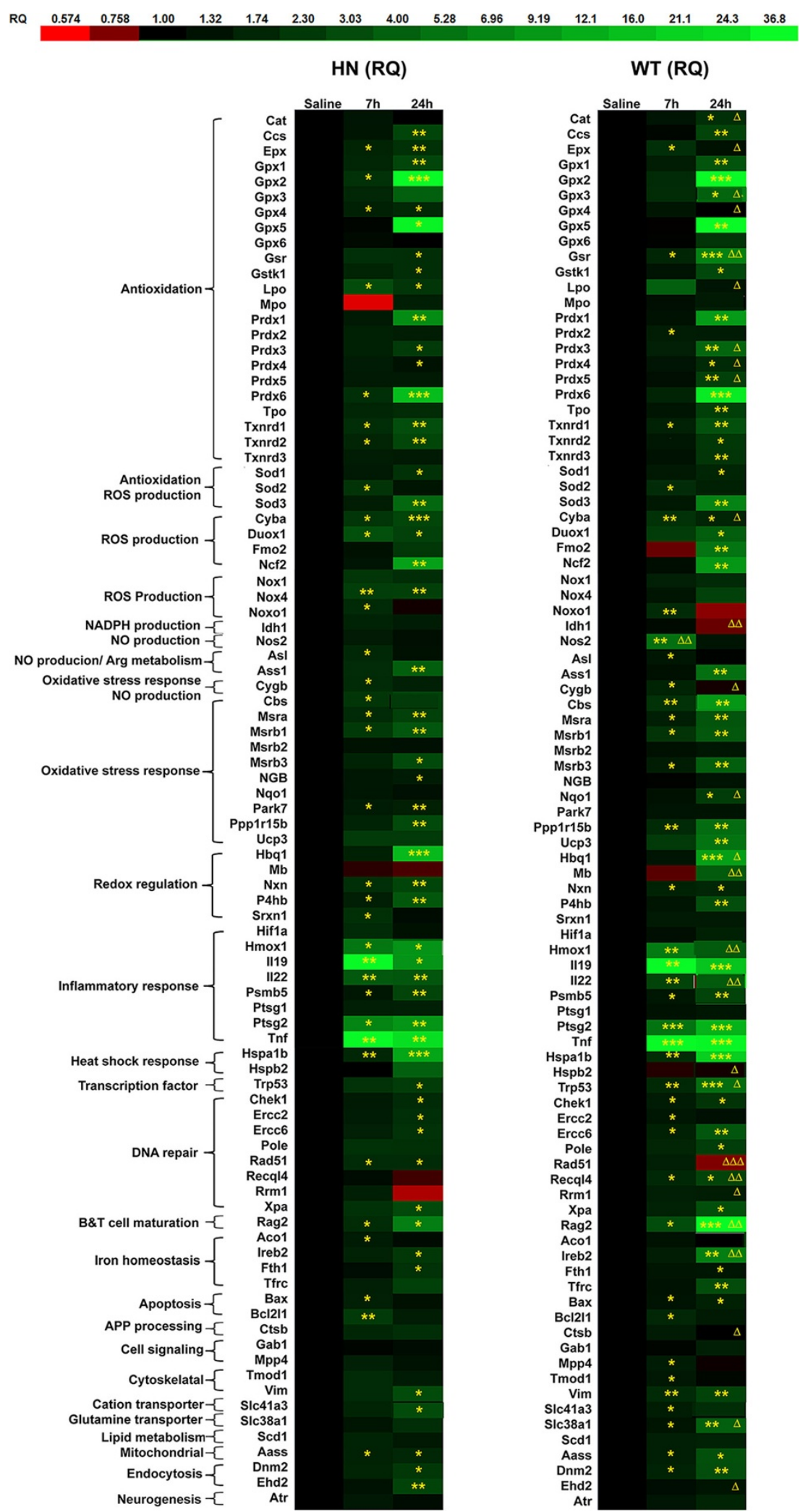

Figure 3 (See legend on next page.) 
(See figure on previous page.)

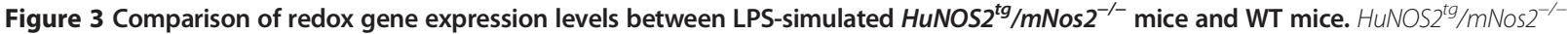
and WT mice were injected with $10 \mathrm{mg} / \mathrm{kg}$ LPS, or with saline as a control, and brains were removed after 7 or 24 hours. RNA was extracted, reverse transcribed, and target gene expression was measured by q-PCR. Fold changes (RQ) were determined for HuNOS2 $2^{\text {tg }} / \mathrm{mNos}^{-1-}$ and WT mice using appropriate saline-injected animals as the comparator for each mouse strain. RQ values were linearized by Log2 conversion, and then subjected to conditional formatting whereby red cells denote lower expression and green cells denote higher expression according to the color scale. Significant differences in gene expression for LPS treated as compared to same strain saline-injected controls were determined by student's $t$-test $\left({ }^{*} p \leq 0.05\right.$, ${ }^{* *} \mathrm{p}<0.01$, ${ }^{* * *} \mathrm{p}<0.001$ ). Significant differences in gene expression between $\mathrm{WT}$ and HuNOS $2^{\mathrm{tg}} / \mathrm{mNos} 2^{-1-}$ mice at specific time points were determined by student's t-test $(\Delta p \leq 0.05, \Delta \Delta p<0.01, \Delta \Delta \Delta p<0.001) . n=3$ mice per group.

analyzed expression of selected genes in $\mathrm{mNOS} 2^{-/-}$mice (no NO) and compared these mRNA levels to the levels found in high NO (WT mice) and to mice with "human"like levels $\left(\mathrm{HuNOS} 2^{t g} / m N o s 2^{-/-}\right)$. Examples of gene expression patterns are shown in Figure 4. We found LPS-stimulated genes (cystathione-b- synthase; glutathione peroxidase-3; Figure $4 \mathrm{~A}, \mathrm{~B}$ ) that were significantly changed only in WT mice compared to either $\mathrm{HuNOS} 2^{t g} / \mathrm{mNos} 2^{-/-}$ or $m N O S 2^{-/-}$, and thus appeared to be dependent on high levels of NO production. Alternatively, heme oxygenase -1 (Ho-1) and heat shock protein 27 (Hspb2, Hsp27) were specifically altered in the $\mathrm{HuNOS} 2^{t g} / \mathrm{mNos} 2^{-/-}$mice brain (Figure 4 C, D). Ho-1 mRNA levels increased with LPS treatment whereas no significant change in $\mathrm{Ho}-1$ was found for either WT or the $m$ Nos 2 knockout mice. Basal expression levels of $H s p-27$, however, were increased in

Table 1 LPS-stimulated gene expression differences

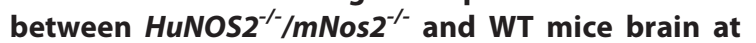
24 hrs post injection

\begin{tabular}{|c|c|c|}
\hline $\begin{array}{c}\text { Gene } \\
\text { abbreviation }\end{array}$ & Gene name & $\begin{array}{l}\text { Significantly } \\
\text { different }\end{array}$ \\
\hline *Prdx3 & Periredoxin 3 & $\mathrm{WT}>\mathrm{HN}$ \\
\hline Prdx4 & Periredoxin 4 & $\mathrm{WT}>\mathrm{HN}$ \\
\hline Prdx5 & Periredoxin 5 & $\mathrm{WT}>\mathrm{HN}$ \\
\hline Gsr & Glutathione reductase & $\mathrm{WT}>\mathrm{HN}$ \\
\hline Cyba & NADPH oxidase Cytochrome- b subunit a & $\mathrm{HN}>\mathrm{WT}$ \\
\hline Cat & Catalase & $\mathrm{WT}>\mathrm{HN}$ \\
\hline Epx & Eosinophil peroxidase & $\mathrm{HN}>\mathrm{WT}$ \\
\hline Gpx4 & Glutathione peroxidase 4 & $\mathrm{HN}>\mathrm{WT}$ \\
\hline $\mathrm{Nqo1}$ & NAD(P)H dehydrogenase 1-Quinone 1 & $\mathrm{WT}>\mathrm{HN}$ \\
\hline Gsr & Glutathione reductase & $\mathrm{WT}>\mathrm{HN}$ \\
\hline${ }^{*}$ Lpo & lactoperoxidase & $\mathrm{HN}>\mathrm{WT}$ \\
\hline Ireb2 & Iron responsive element binding protein 2 & $\mathrm{WT}>\mathrm{HN}$ \\
\hline RAD51 & RAD51 recombinase & $\mathrm{HN}>\mathrm{WT}$ \\
\hline${ }^{*}$ Recql4 & REC-q like protein 4 (helicase) & ND \\
\hline $\mathrm{Hbq} 1$ & Hemoglobin theta 1 & $\mathrm{WT}>\mathrm{HN}$ \\
\hline$* \mid \mathrm{L}-22$ & Interleukin 22 & $H N>W T$ \\
\hline Rag2 & Recombination activating gene 2 & $\mathrm{WT}>\mathrm{HN}$ \\
\hline Slc38a1 & $\begin{array}{c}\text { Solute Carrier 38a1 } \\
\text { (glutamine transporter) }\end{array}$ & $\mathrm{WT}>\mathrm{HN}$ \\
\hline
\end{tabular}

*Gene analysis was confirmed by additional RT-PCR (See Figure 4). mice expressing human NOS2 but not in WT or $m N o s 2^{-/-}$ mice. Finally, as shown in Figure 4 (E,F) mice lacking $m N o s 2$ and thus unable to increase NO in response to LPS showed significantly higher levels of lactoperoxidase (Lpo) and lower levels of aconitase1 (Aco1).

Gene changes between $\mathrm{HuNOS} 2^{t g} / m N o s 2^{-/-}$and WT mice under non- immune stimulated conditions provide insights into the potential physiological impact of an inherent background difference in WT mice that have high levels of $\mathrm{NO}$ and in $\mathrm{HuNOS} 2^{t g} / \mathrm{mNos} 2^{-/-}$mice that have low levels of NO. However, NOS2 is an inducible gene and any non-stimulated change in brain expression levels when the HuNOS2 gene is inserted into the mouse genome is puzzling. NOS 2 translation and transcription are well-known to be regulated by disease-based immune activators including LPS and cytokines via multiple membrane receptors. For the human gene, NOS 2 gene expression is also regulated by non 'cytokine'- like factors including $\beta$-catenin/Wnt2, epidermal growth factor (EGF), colony stimulating factor 1 (CSF1) and hormones such as testosterone [30,38,48]. Geller and colleagues [25,30] have shown specific upstream sites in the human NOS 2 promoter that alter gene regulation. One of these sites mediates basal promoter activity of the NOS 2 gene and functions independently of known cytokine responsive regulatory elements in the gene promoter. The physiological role of basal induction of the NOS 2 gene in human cells is not well studied but has been implicated in changes that lead to cancer $[48,49]$. To determine if nonstimulated "basal" changes could be found in mice expressing the human NOS 2 gene we compared mRNA levels of selected genes between saline- treated $m N o s 2^{-/-}$ (where $\mathrm{NO}$ is not produced) and $\mathrm{HuNOS} 2^{t g} / \mathrm{mNos}^{-/-}$ mice that express a human NOS 2 gene and promoter and produce human levels of NO. Of the genes tested (Figure 4), Hsp27 was found to demonstrate a significant change in saline-treated (control) levels of mRNA expression with no significant difference in LPS-stimulated mRNA expression.

\section{Immune gene profiles are altered in mice expressing the} huNOS2 gene

We next determined if changes in the tissue redox responses in $\mathrm{HuNOS} 2^{t g} / \mathrm{mNos} 2^{-/-}$mice could also impact cytokine production in the brain. Thus, gene expression 

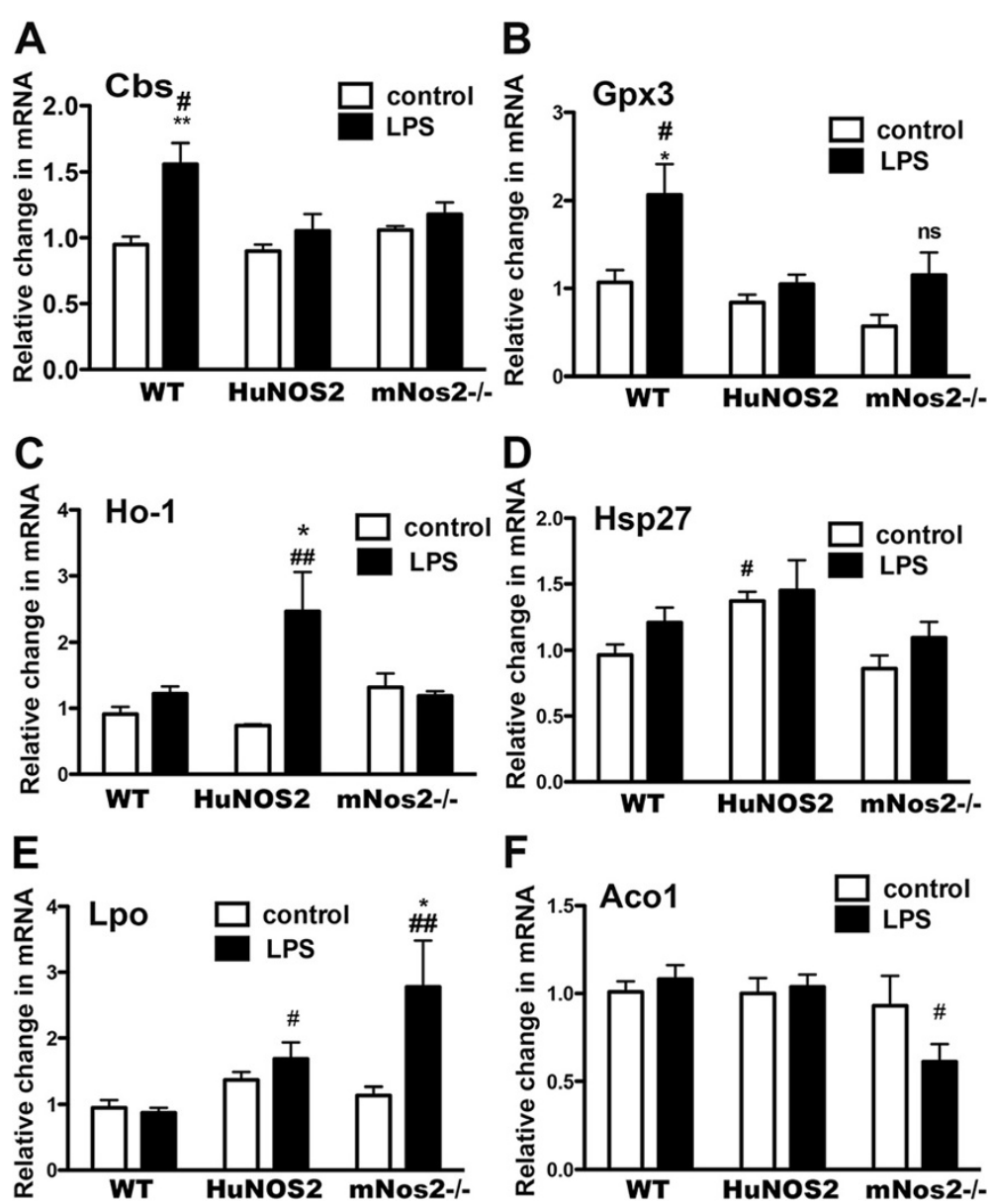

Figure 4 Comparison of gene expression for selected genes. Genes that showed changes in expression levels between WT and HuNOS2t9/ mNos $2^{-1-}$ mice were also examined for expression levels in $\mathrm{mNos}^{-1-}$ mice. Brain lysates were prepared from saline-injected (white bars) and LPS-injected (black bars) mNos2 knockout mice as described and gene expression measured using qRT-PCR. Average fold changes ( \pm sem) for each gene in saline and LPS-treated conditions were determined using the average WT saline-injected value as comparator. Statistical significance across genotypes and treatment was determined using two-way ANOVA (GraphPad Software, San Diego CA). Significance was set at $p \leq 0.05$. ${ }^{*} \mathrm{p}<0.05$; ${ }^{* *} \mathrm{p}<0.01$ for comparisons with treatment; \#p <0.05, \#\#p<0.01 for comparisons across strains. $\mathrm{n}=5-6$ mice per group.

levels for specific chemokines, pro-inflammatory and antiinflammatory cytokines were measured in $\mathrm{HuNOS}^{t g}$ / $m N o s 2^{-1-}$ mice and compared to WT and $m N_{o s} 2^{-1-}$ mice at $24 \mathrm{hrs}$ after LPS injection. We also measured the same genes in brain lysates from the HuNOS2 $2^{t g} / A P P S w D I /$ $m N o s 2^{-/-}$to understand if brain $\mathrm{A} \beta$ production and accumulation altered cytokine mRNA levels when the HuNOS2 gene is expressed. All mice were injected with $10 \mathrm{mg} / \mathrm{kg}$ LPS or saline and brain lysates prepared in the same manner as described previously. Gene expression levels are presented in Figure 5 as the average $( \pm$ sem) fold changes observed under untreated and LPS- treated conditions. As shown, pro-inflammatory (Il-1 $\beta$; TNF $\alpha, I L-6)$ and anti-inflammatory $(A g 1, I L-r n)$ mRNA levels significantly increased with LPS- treatment in each of the mouse strains examined (Figure 5 A-E). Genotype specific differences were also observed. Significantly greater responses were observed in APPhuNOS2 mice for Il-6, in $\mathrm{mNos}^{-/-}$ mice for $A g 1$ and in $H u N O S 2^{t g} / m N o s 2^{-/-}$mice for Tnfa. $T g f \beta$ failed to show a response to LPS in any of the mouse strains (Figure 5F). Chemokine gene expression patterns were dependent on the specific chemokine. Cx3cr1 mRNA expression (Figure 5G) was not significantly altered by treatment with LPS in any of the mouse strains. For Ccr2, LPS- treatment reduced levels of mRNA expression in brain lysates from $\mathrm{HuNOS} 2^{t g} / \mathrm{mNos}^{-/-}$, APPHuNOS2 and $m N_{o s} 2^{-/}$mice but not in WT mice (Figure 5H). However, increased LPS-mediated expression of $C \mathrm{cr} 1$ was found only in the strains that expressed HuNOS $2^{t g} / \mathrm{mNos}^{-1-}$. We also examined a microglia marker that is found in patients with $\mathrm{AD}[9,10]$. The Itgax gene encodes the CD11c protein and was significantly increased only in $\mathrm{HuNOS2^{tg }} / \mathrm{APPS} w \mathrm{DI} / \mathrm{mNos}^{-{ }^{--}}$mice (Figure 5J). Finally, to determine if the production of $A \beta$ peptides and accumulation of amyloid altered nitrate and nitrite levels in brain, we measured NOx levels as 


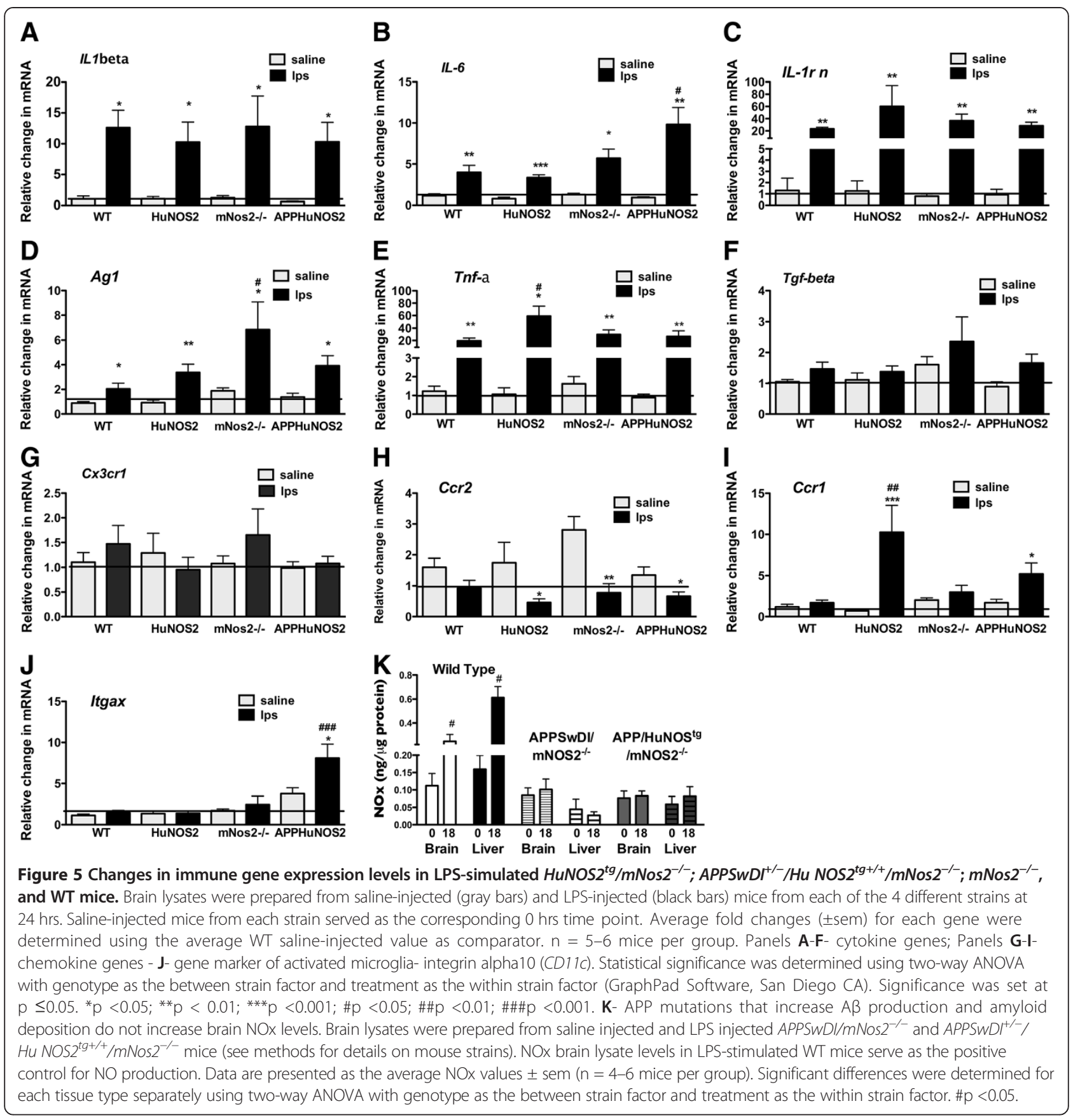

described previously in brain and liver lysates from HuNOS2 $2^{t g} / A P P S w D I / m N o s 2^{-/-}$and APPSwDI/mNos $2^{-/-}$ mice using WT as the positive control. No significant changes in NOx levels were observed for mice from either of the APP strains (Figure 5K).

The observed changes in brain gene expression between WT, HuNOS2 $2^{t g} / m N o s 2^{-/-}$and $m N o s 2^{-/-}$mice suggested that strain-dependent physiological differences may also be found. LPS treatment is well known to affect the brain /blood interface by increasing small hemorrhages resulting in brain accumulation of red blood cells and hemosiderin, a break down product of heme iron [50-52]. Since the blood brain barrier integrity is regulated, in part, by NO-dependent metalloprotease (MMP) activity $[52,53]$ we compared the average number of brain microbleeds per section ( \pm sem) in WT, HuNOS2 $2^{t g} / m N o s 2^{-/-}$and $m N o s 2^{-/-}$ mice. Microbleeds were assessed using Prussian blue histochemistry as previously described [51,52] and categorized as "small" (Figure 6A) or "large" (Figure 6B). As shown in Figure 6C, LPS-treatment initiated a significant increase in large microbleeds compared to saline-treated (control) brains in both $\mathrm{HuNOS} 2^{t g} / \mathrm{mNos}^{-/-}$and $m N o s 2^{-/-}$mice. 

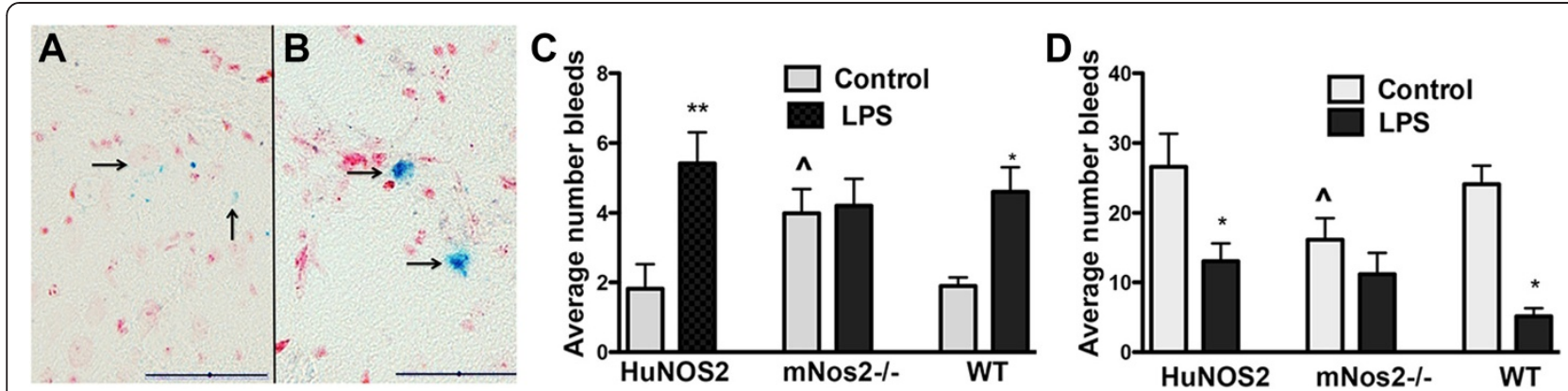

Figure 6 Mouse stain specific differences in brain microhemorrhage. The total number of microhemorrhages per brain section were

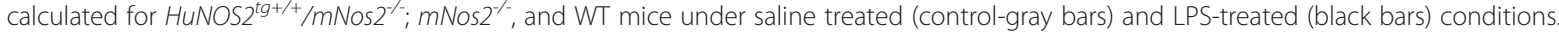
Panel A; B-typical view of small ( $<20$ microns; A) and large ( $>20$ microns; B) microbleeds observed in brain sections using Prussian blue histochemistry to identify hemisedrin deposits. Panel C; D- Data represent the average number $(+$ sem) of microbleeds/section ( $n$ - 4-7 mice of each strain) for control and LPS-treated mice. Significant differences were determined using two-way ANOVA with genotype as the between strain factor $(\wedge p<0.05)$ and treatment as the within strain factor (\#p < 0.05; \#\#p<0.01).

Mice lacking Nos2, however, showed a significant increase in untreated control brain bleeds when compared to un-

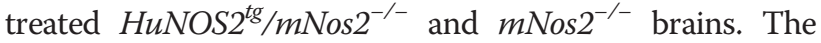
average untreated value from $m N o s 2^{-/-}$brains was not different compared to LPS-treated $m N o s 2^{-1-}$ brains. A similar pattern was observed for small bleeds in terms of the strain differences. However, the number of small bleeds was significantly lower with LPS treatment (Figure 6D).

\section{Discussion}

NO and superoxide anion are primary redox molecules that establish and regulate tissue redox balance through direct and indirect mechanisms of action. Both NO and superoxide anion are also central components of immunity with regulatory and defensive roles. Thus, it is likely that species differences in production or consumption of either NO or superoxide anion will have evolutionary significance. As a reactive molecule that interacts with multiple proteins and has a relatively long diffusion distance, NO is particularly well suited to impact cellular pathways. The outcome of these reactions is now well known to be dependent on the level of NO $[34,42,48,54,55]$. Thus, understanding how and when NO levels change in a tissue is not only critical to deciphering redox regulated mechanisms but also is critical to unraveling immune processes and immune pathology.

The discovery of miRNA-939 mediated regulation of human iNOS protein translation by Guo et al. [29] has provided a realistic mechanism to explain a long term conundrum: Why is iNOS mediated production of NO different between human and rodent? Our data support their finding and further directly show that these differences in NO production impact the redox, immune and physiological signature of the brain. This was accomplished by reconstituting human NOS 2 into a mouse Nos 2 knockout model, thus providing a useful tool to study NOS2/NO related responses that are relevant to human disease in an in vivo as well as in vitro setting.

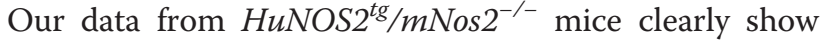
the presence of the binding site for miRNA-939 in the 3'UTR region of the HuNOS2 gene and the presence of a miRNA-939 homolog in the brain, thus recreating a more human-like condition. While $\mathrm{C} 57 \mathrm{Bl} / 6$ mice express miRNA-939, they lack the binding site in the gene and the additional regulatory complexity found in the human NOS2 gene promoter. Geller and colleagues [25,30] have also described unique promoter sites in the human gene that involve non-cytokine based regulatory elements and elicit basal production of NO by NOS2. This difference in NO regulation implies a more varied and complex production of NO in human tissues.

The inability to readily measure nitrite and nitrate levels as a surrogate marker of NO production in human immune cells has provided an increased level of difficulty in charting NO's involvement in specific pathways. As shown in this study, LPS-mediated stimulation of human NOS2 in vivo does not result in measureable increases in brain lysate levels of nitrite and nitrate, the commonly used indicators of NO production. Nitrate and nitrite are clearly not the only reaction product of NO, however, and other reactive nitrogen species are produced as a result of human NOS2 activation during an immune response [39-41]. The directed gene array for $\mathrm{HuNOS} 2^{\mathrm{tg}} / \mathrm{mNos} 2^{-/-}$ mice was designed to provide additional insight into the spectrum of pathways that may be differentially activated by human NOS 2 vs mouse Nos 2 . We specifically chose redox based genes to profile because of NO's inherent redox activity and the role of redox-based regulation in inflammation. In addition, neurodegenerative diseases of aging such as Alzheimer's disease have oxidative stress as a primary component [56-58]. A similar directed array approach has recently been used to delineate redox genes that are changed in humans with Multiple Sclerosis [59]. 
Overall, our array results show that LPS induction in mice expressing reconstituted huNOS2 produced a statistically significantly different pattern of redox gene expression than WT mice. The exact inter-relationships between NOS2 expression levels and specific gene expression levels such as cystathione b synthase $(\mathrm{Cbs})$ and glutathione peroxidase $3(G p x 3)$ are not precisely defined here. For some genes such as $\mathrm{Cbs}$, however, direct connections to NO are known. For example, the enzymatic activity of Cbs protein is reduced when $\mathrm{NO}$ binds to the heme site of the protein, thereby altering the transulfuration pathway and the production of either hydrogen sulfide (H2S) or glutathione (GSH) [60]. These data coupled with the increased expression of glutathione peroxidase- 3 and glutathione reductase in only LPS-treated WT mice imply a regulatory cross talk between glutathione, $\mathrm{H}_{2} \mathrm{~S}$ and high levels of $\mathrm{NO}$ which may not be observed in either the $m N o s 2^{-/-}$or $\mathrm{HuNOS} 2^{t g} / m N o s 2^{-/-}$strains where NO generated via NOS2 is low.

Two other important and specific points can be gleaned from our data set. First, re-constitution of the human NOS2 gene restores gene expression changes that occur as a result of $m$ Nos 2 depletion. For example, genes such as Lpo and Ag1 are elevated only in $\mathrm{mNos}^{-/-}$mice. In mice expressing human NOS2 mRNA, both Lpo and Ag1 expression levels are restored to the WT equivalent. These data support the functionality of the HuNOS2 gene in the $\mathrm{mNos}^{-/-}$mouse background. Secondly, the human NOS2 gene shows unique characteristics that are not found in either WT or mice lacking $m N o s 2$. For example, three key genes associated with disease, that is, heme-oxygenase 1 (Ho1), TNF $\alpha$ and Ccr1 are upregulated in HuNOS2 $2^{t g}$ / $m N o s 2^{-/-}$mice brain compared to either WT or $m \mathrm{Nos}^{-/-}$ mice. These changes are likely to impact both the response to hypoxia and the response of the brain to immune challenge. The presence of human NOS2 also mitigates the apparently "leaky" cerebral vessels found in $m N o s 2^{-1-}$ mice. Increased constitutive levels of both large and small microglia bleeds were observed in knock-out mice. Although LPS altered the number of hemorrhage sites in WT and HuNOS2 $2^{t g} / m N o s 2^{-/-}$mice in a complex manner, addition of the human NOS 2 gene prevented these changes under normal, non-LPS simulated levels, thus mimicking WT mice.

Differences in NO production and its complex action in the brain's redox environment clearly contribute to the frequently conflicting data and disparate views of NO's role in disease, particularly when mouse models are used. For neurodegenerative disease, $\mathrm{NO}$ is commonly viewed as a contributor to neuronal death in the brain through its ability to interact with superoxide ion to form reactive oxygen species that kill the cell $[61,62]$. A good example of this is the expression of iNOS in neurons in APP mouse models of $\mathrm{AD}$ and in patients with $\mathrm{AD}$. Cortical neurons from the APPSw (Tg2576) mouse model of AD show iNOS immunoreactivity around amyloid deposits and in neurons associated with intracellular $A \beta$ [63]. While footprints of oxidation are found in this micro-environment, the primary event that generates reactive oxygen species may actually be the loss of NO's role as a superoxide scavenger to reduce oxidative stress $[42,64]$. Local oxidants such as reactive iron can interact with $\mathrm{NO}$, leading to the formation of nitrotyrosine and reducing local NO levels [65]. In mouse brain where NO levels are likely to be high, the impact of the loss of NO in the environment will be different than in human brain where the inherent levels of NO generated by iNOS are likely to be restricted by the complexity of the NOS 2 gene promoter and by miRNA regulation of translation. Rodrigo et al. [63] clearly show that increased expression of iNOS in APPSw mice is accompanied by increased $\mathrm{A} \beta$ and oxidative outcomes, but these are not accompanied by neuronal death. APPSw Tg2576 mice do not show neuronal loss [66]. In contrast, the removal of $m N o s 2$ as shown in the APPSw/NOS $2^{-1-}$

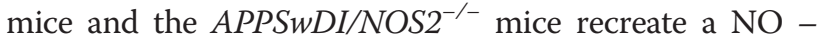
poor micro-environment and do demonstrate neuronal death. We also have recently shown that reconstitution of human NOS2 into mice expressing mutated human APP and that lack $m N o s 2$ also proceed to neuronal loss [67], further suggesting a critical role of NO levels. FernandezVizarra [68] has carefully examined the expression of nNOS and iNOS at different stages of $\mathrm{AD}$ in neurons from humans with $\mathrm{AD}$. Interestingly, their data demonstrated an increasing level of expression of nNOS followed by increasing ecotopic expression of iNOS in cortical neurons. They also observed that the increased expression of NOS enzymes with progression of AD pathology was frequently accompanied by nitrotyrosine immunoreactivity but was only rarely associated with signs of neuronal death. They concluded that the presence of NO was protective until "oxidative" events became a dominant cellular pathology. The inherently different regulation of $\mathrm{NO}$ levels produced by human iNOS during immune activation as we show herein and/or the consumption of arginine, the sole substrate of iNOS are likely to be additional factors that lead to the worsening pathology in humans with AD. Thus the levels of NO and its perspective chemical biology in the microenvironment is an important determinant of outcome.

Mouse genetic models are, and undoubtedly will remain, a significant tool to study neurodegeneration and neurological disease. The importance of their contribution to our understanding of the disease process in turn depends on how the genetic change enables production of a pathological pathway that resembles the pathway found in humans. The importance of this question ultimately depends on the degree of association of the gene changes with disease. As discussed previously, Zhang's [17] data 
derived from gene networks analysis of autopsied brain samples from humans with AD provide important insights. Their studies clearly show a dominant contribution of microglial/immune genes to multiple clinical co-variants found in patients with AD. However, NO mediated network associations with AD pathology are minimal. It is likely, then, that consideration of differences between human and mouse NOS 2 and the impact this has on the brain's redox environment may be useful in studying human disease including AD.

\section{Methods}

\section{Animals}

All animal experiments were performed in accordance with protocols approved by the Institutional Animal Care and Use committee at Duke University Medical Center under the NIH Guide for the Utilization and Care of Vertebrate Animals Used in Testing, Research and Training.

\section{Mice strains: HuNOS2 $2^{t g+/+} / m N o s 2^{-/-}$mice}

The HuNOS $2^{t g+/+} / m N o s 2^{-/-}$strain was developed and characterized by Vitek et al. as described [45].

\section{APPSWDI $I^{+/-} / \mathrm{Hu} \mathrm{NOS}^{\mathrm{tg}+/+} / \mathrm{mNos} 2^{-/-}$mice}

Homozygous APPSwDI/mNos2 ${ }^{-/-}$(CerebroVascular amyloid$N o s 2^{-1-}$ or CVN-AD) mice were produced by crossing mice expressing the vasculotropic Swedish K760N/M671L, Dutch E693Q and Iowa D694N human APP mutations under control of the Thy-1 promoter with $m N o s 2^{-/-}$ (B6 129P2NOS2 $2^{\text {taulLau }} / J$ ) mice [45]. These mice were then crossed to $\mathrm{HuNOS} 2^{t g+/+} / \mathrm{mNos} 2^{-/-}$mice to generate the APPSwDI $I^{+/-} / \mathrm{Hu} \mathrm{NOS} 2^{t g+/+} / m N o s 2^{-/-}$strain.

\section{Control mice}

$m$ Nos $2^{-/-}$(B6 129P2NOS2 $2^{\text {tau1Lau }} / \mathrm{J}$ ) and C57Bl/6 WT mice were purchased from Jackson Laboratory, Bar Harbor $\mathrm{ME}$ and produced through the barrier breeding colonies at Duke University. All mice were genotyped in a standard fashion.

\section{LPS treatment}

Mice between the ages of 36-40 weeks of age (mixed genders) were $i v$ injected with $10 \mathrm{mg} / \mathrm{kg}$ LPS or saline $(0.9 \% \mathrm{NaCl})$ via the tail vein. Mixed genders were used in the analyses and gender based-differences were not investigated. Mice were allowed to recover on heated pads and then were humanely euthanized at 7 and $24 \mathrm{hrs}$ after the injection with a lethal mixture of ketamine/xylazine. Each mouse was intracardially perfused with approximately 25 mls of phosphate buffered saline (PBS). Hemispheres from perfused brains and 2-3 lobes from each liver were then rapidly removed, immediately frozen in liquid nitrogen and the cryo-preserved tissue was pulverized under liquid nitrogen for use in the assays. The remaining hemispheres were fixed in $4 \%$ paraformaldehyde and passed through sucrose gradients for sectioning on a freezing microtome.

\section{Prussian blue staining}

Sagittal sections (25 microns) were cut from fixed brain, mounted and air-dried on slides for staining using the Perls protocol. After rehydration, sections were reacted with acidic potassium ferrocynanide (2 gm/100 mls) for 30 mins. Sections were then counterstained with neutral red. The number of microbleeds was counted at $20 \times$ magnification for 4 complete brain sections/mouse located between $0.6-2.04 \mathrm{~mm}$ lateral to the bregma for a minimum of 4 mice per strain. Microbleeds were identified as bright blue spots and were separated into two categories; large (>20 microns) and small ( $<20$ microns) (see Figure 6).

\section{NOx assay}

For the NOx assay $40 \mathrm{mg}$ of frozen pulverized brain or liver tissue from each brain were boiled in $250 \mu \mathrm{l}$ PBS buffer for $10 \mathrm{~min}$. After centrifugation to pellet, total nitrite and nitrate $(\mathrm{NOx})$ content of the supernatants were measured using a Sievers Nitric Oxide Analyzer under reduction by vanadium (III) chloride $\left(\mathrm{VCl}_{3}\right)$ in $1 \mathrm{~N} \mathrm{HCl}$, heated to $95^{\circ} \mathrm{C}$ [69]. NOx levels were normalized to total protein content of the supernatants as determined by BCA assays.

\section{qRT-PCR}

Total RNA was extracted from approximately $40 \mathrm{mg}$ of frozen pulverized brain tissue, which was homogenized using a Bullet Blender with RNase free $0.5 \mathrm{~mm}$ zirconium oxide beads (Next Advance) in TRIzol reagent (Life Technologies). cDNA was produced using the cDNA High Capacity kit (Life Technologies) according to the manufacturer's instructions. Real-time PCR was performed using TaqMan Gene Expression assays (Life Technologies) also according to the manufacturer's instructions and as previously described [70]. Data were normalized to either $18 \mathrm{~s}$ or $\beta$-actin. Specific miRNA was reverse transcribed using the TaqMan MicroRNA Reverse Transcription Kit (Life Technologies) and the specific RT primer supplied with each TaqMan miRNA assay. Quantitative PCR was then run using the BioRad CFX96 Touch Real Time PCR detection system. Average fold change values (RQ) were determined by $2^{(-\Delta \Delta C t)}$ method using saline injection as the comparator for individual strain samples [47].

Primers: Primers for WT mNos2 were: Forward 5'TTA CGT CCA TCG TGG ACA GC-3' and for Reverse 5'-TGG GCT GGG TGT TAG TCT TA-3'. Primers for the human 3'UTR were: Forward- 5' CCC CCA GCC TCA AGT CTT ATT TC-3' and for Reverse- 5'-CAG CAG CAA GTT CCA TCT TTC AC-3'. Primers for dectection of miRNA-939 were purchased as a TaqMan 
MicroRNA assay (Assay name- hsa-mir-939) from Life Technologies.

\section{Statistical analysis}

Data are presented as average values \pm SEM. Where appropriate, significant changes within strain were determined using student's $t$-test or one-way ANOVA while statistical significance between strains and treatments was determined using two-way ANOVA (GraphPad Software, San Diego CA). Significance was set at $\mathrm{p} \leq 0.05$.

\section{Competing interests}

Other- Michael P. Vitek is an employee of Duke University and is the CEO of Cognosci, Inc., Research Triangle Park, North Carolina. Carol A. Colton has spousal-based, non-financial competing interest with Cognosci, Inc. and with Oncotide, Inc. Vitek and Colton conflict of interest is managed by the Duke Committee on Conflict of Interest. Remaining authors (Wink, Ridnour, Hoos, Wilson, Jansen, Everhart) have no competing interests.

\section{Authors' contributions}

$\mathrm{MH}$ carried out the molecular genetic studies and the measurement of NOx activity; DW provided guidance on the chemical biology of $\mathrm{NO}$ and provided interpretation of results; LR provided interpretation of results and assisted with production of the manuscript; JW carried out the animal experimentation procedures; MJ carried out molecular gene analysis experiments; AE performed all histochemical studies; MV provided guidance on the molecular biological and mouse genetics; CC initiated and supervised the experimental aspects of the project including data analysis and production of the manuscript. All authors read and approved the final manuscript.

\section{Author details}

'Department of Neurosurgery, Stonybrook Health Sciences, Stony Brook, NY 11794, USA. ²Department of Neurology, Duke University Medical Center, Durham, NC 27710, USA. ${ }^{3}$ Radiation Biology Branch, National Cancer Institute, National Institutes of Health, Bethesda, MD 20892, USA

Received: 15 May 2014 Accepted: 10 October 2014

Published: 17 November 2014

\section{References}

1. Galasko D, Bell J, Mancuso JY, Kupiec JW, Sabbagh MN, van Dyck C, Thomas RG, Aisen PS: Clinical trial of an inhibitor of RAGE-abeta interactions in alzheimer disease. Neurology 2014, 82:1536-1542.

2. Salloway S, Sperling R, Fox NC, Blennow K, Klunk W, Raskind M, Sabbagh M, Honig LS, Porsteinsson AP, Ferris S, Reichert M, Ketter N, Nejadnik B, Guenzler V, Miloslavsky M, Wang D, Lu Y, Lull J, Tudor IC, Liu E, Grundman M, Yuen E, Black R, Brashear HR, Bapineuzumab 301 and 303 clinical trial investigators: Two phase 3 trials of bapineuzumab in mild-to-moderate Alzheimer's disease. N Engl J Med 2014, 370:322-333.

3. Becker RE, Greig NH, Giacobini E: Why do so many drugs for alzheimer's disease fail in development? Time for new methods and new practices? J Alzheimers Dis 2008, 15:303-325.

4. Schor NF: What the halted phase III gamma-secretase inhibitor trial may (or may not) be telling us. Ann Neurol 2011, 69:237-239.

5. Finch CE, Marchalonis JJ: Evolutionary perspectives on amyloid and inflammatory features of Alzheimer disease. Neurobiol Aging 1996, 17:809-815.

6. Griffin WS, Sheng JG, Royston MC, Gentleman SM, McKenzie JE, Graham DI Roberts GW, Mrak RE: Glial-neuronal interactions in alzheimer's disease: the potential role of a 'cytokine cycle' in disease progression. Brain Pathol 1998, 8:65-72.

7. Mrak RE, Griffin WS: Glia and their cytokines in progression of neurodegeneration. Neurobiol Aging 2005, 26:349-354.

8. Eikelenboom P, van Exel E, Hoozemans JJ, Veerhuis R, Rozemuller AJ, van Gool WA: Neuroinflammation - an early event in both the history and pathogenesis of alzheimer's disease. Neurodegener Dis 2010, 7:38-41.
9. Akiyama $\mathrm{H}, \mathrm{McGeer} \mathrm{PL}$ : Brain microglia constitutively express beta-2 integrins. J Neuroimmunol 1990, 30:81-93.

10. McGeer PL, Itagaki S, Tago H, McGeer EG: Reactive microglia in patients with senile dementia of the alzheimer type are positive for the histocompatibility glycoprotein HLA-DR. Neurosci Lett 1987, 79:195-200

11. Jones L, Holmans PA, Hamshere ML, Harold D, Moskvina V, Ivanov D, Pocklington A, Abraham R, Hollingworth P, Sims R, Gerrish A, Pahwa JS, Jones N, Stretton A, Morgan AR, Lovestone S, Powell J, Proitsi P, Lupton MK, Brayne C, Rubinsztein DC, Gill M, Lawlor N, Lynch A, Morgan K, Brown KS, Passmore PA, Craig D, McGuinness B, Todd S, et al: Genetic evidence implicates the immune system and cholesterol metabolism in the aetiology of alzheimer's disease. PLoS One 2010, 5:e13950.

12. Kamboh MI, Demirci FY, Wang X, Minster RL, Carrasquillo MM, Pankratz VS, Younkin SG, Saykin AJ, for the Alzheimer's Disease Neuroimaging Initiative, Jun G, Baldwin C, Logue MW, Buros J, Farrer L, Pericak-Vance MA, Haines JL, Sweet RA, Ganguli M, Feingold E, DeKosky ST, Lopez OL, Barmada MM: Genome-wide association study of alzheimer's disease. Transl Psychiatry 2012, 2:e117.

13. Morgan K: The three new pathways leading to alzheimer's disease. Neuropathol Appl Neurobiol 2011, 37:353-357.

14. Colton CA, Brown CM, Vitek MP: Sex steroids, APOE genotype and the innate immune system. Neurobiol Aging 2005, 26:363-372.

15. Crehan H, Holton P, Wray S, Pocock J, Guerreiro R, Hardy J: Complement receptor 1 (CR1) and alzheimer's disease. Immunobiology 2012, 217:244-250.

16. Bertram L, Lange C, Mullin K, Parkinson M, Hsiao M, Hogan MF, Schjeide BM, Hooli B, Divito J, lonita I, Jiang H, Laird N, Moscarillo T, Ohlsen KL, Elliott K, Wang X, Hu-Lince D, Ryder M, Murphy A, Wagner SL, Blacker D, Becker KD, Tanzi RE: Genome-wide association analysis reveals putative alzheimer's disease susceptibility loci in addition to APOE. Am J Hum Genet 2008, 83:623-632.

17. Zhang B, Gaiteri C, Bodea LG, Wang Z, McElwee J, Podtelezhnikov AA Zhang C, Xie T, Tran L, Dobrin R, Fluder E, Clurman B, Melquest S, Narayanan M, Suver C, Shah H, Mahajan M, Gillis T, Mysore J, MacDonald M, Lamb JR, Bennett DA, Molony C, Stone DJ, Gudnason V, Myers AJ, Schadt EE, Neumann H, Zhu J, Emilsson V: Integrated systems approach identifies genetic nodes and networks in late-onset alzheimer's disease. Cell 2013, 153:707-720.

18. Guerreiro R, Hardy J: TREM2 and neurodegenerative disease. N Engl J Med 2013, 369:1569-1570

19. Seok J, Warren HS, Cuenca AG, Mindrinos MN, Baker HV, Xu W, Richards DR, McDonald-Smith GP, Gao H, Hennessy L, Finnerty CC, Lopez CM, Honari S, Moore EE, Minei JP, Cushieri J, Bankey PE, Johnson JL, Sperry J, Nathens AB, Billiar TR, West MA, Jeschke MG, Klein PH, Gamelli RL, Gibran NS, Brownstein BH, Miller-Graziano C, Calvano ES, Mason PH, Cobb JP, et al: Genomic responses in mouse models poorly mimic human inflammatory diseases. Proc Natl Acad Sci U S A 2013, 110:3507-3512.

20. Takao K, Miyakawa T: Genomic responses in mouse models greatly mimic human inflammatory diseases. Proc Natl Acad Sci U S A 2014, Aug 4, E pub ahead of print.

21. Mestas J, Hughes CC: Of mice and not men: differences between mouse and human immunology. J Immunol 2004, 172:2731-2738.

22. Colton CA: Induction of nitric oxide in cultured microglia: evidence for a cytoprotective role. Adv Neuroimmunol 1995, 5:491-503.

23. Colton C, Wilt S, Gilbert D, Chernyshev O, Snell J, Dubois-Dalcq M: Species differences in the generation of reactive oxygen species by microglia. Mol Chem Neuropathol 1996, 28:15-20.

24. Weinberg JB, Misukonis MA, Shami PJ, Mason SN, Sauls DL, Dittman WA Wood ER, Smith GK, McDonald B, Bachus KE, Haney AF, Granger DL: Human mononuclear phagocyte inducible nitric oxide synthase (iNOS): analysis of iNOS mRNA, iNOS protein, biopterin, and nitric oxide production by blood monocytes and peritoneal macrophages. Blood 1995, 86:1184-1195.

25. Taylor BS, de Vera ME, Ganster RW, Wang Q, Shapiro RA, Morris SM Jr, Billiar TR, Geller DA: Multiple NF-kappaB enhancer elements regulate cytokine induction of the human inducible nitric oxide synthase gene. J Biol Chem 1998, 273:15148-15156.

26. Schneemann M, Schoeden G: Macrophage biology and immunology: man is not a mouse. J Leukoc Biol 2007, 81:579. discussion 580. 
27. Haley PJ: Species differences in the structure and function of the immune system. Toxicology 2003, 188:49-71.

28. Ganster RW, Taylor BS, Shao L, Geller DA: Complex regulation of human inducible nitric oxide synthase gene transcription by Stat 1 and NF-kappa B. Proc Natl Acad Sci U S A 2001, 98:8638-8643.

29. Guo Z, Shao L, Zheng L, Du Q, Li P, John B, Geller DA: miRNA-939 regulates human inducible nitric oxide synthase posttranscriptional gene expression in human hepatocytes. Proc Natl Acad Sci U S A 2012, 109:5826-5831.

30. Du Q, Park KS, Guo Z, He P, Nagashima M, Shao L, Sahai R, Geller DA, Hussain SP: Regulation of human nitric oxide synthase 2 expression by Wnt beta-catenin signaling. Cancer Res 2006, 66:7024-7031.

31. Guo Z, Shao L, Du Q, Park KS, Geller DA: Identification of a classic cytokine-induced enhancer upstream in the human iNOS promoter. FASEB J 2007, 21:535-542.

32. Kleinert H, Wallerath $T$, Fritz G, Ihrig-Biedert I, Rodriguez-Pascual F, Geller DA, Forstermann U: Cytokine induction of NO synthase II in human DLD-1 cells: roles of the JAK-STAT, AP-1 and NF-kappaB-signaling pathways. Br J Pharmacol 1998, 125:193-201.

33. Kobzik L: Translating NO biology into clinical advances: still searching for the right dictionary? Am J Respir Cell Mol Biol 2009, 41:9-13.

34. Wink DA, Hines HB, Cheng RY, Switzer CH, Flores-Santana W, Vitek MP, Ridnour LA, Colton CA: Nitric oxide and redox mechanisms in the immune response. J Leukoc Biol 2011, 89:873-891.

35. Colton CA, Wilcock DM, Wink DA, Davis J, Van Nostrand WE, Vitek MP: The effects of NOS2 gene deletion on mice expressing mutated human AbetaPP. J Alzheimers Dis 2008, 15:571-587.

36. Hsiao K, Chapman P, Nilsen S, Eckman C, Harigaya Y, Younkin S, Yang F, Cole G: Correlative memory deficits, abeta elevation, and amyloid plaques in transgenic mice. Science 1996, 274:99-102.

37. Sullivan PM, Mezdour H, Quarfordt SH, Maeda N: Type III hyperlipoproteinemia and spontaneous atherosclerosis in mice resulting from gene replacement of mouse apoe with human apoe*2. J Clin Invest 1998, 102:130-135.

38. Geller DA, Billiar TR: Molecular biology of nitric oxide synthases. Cancer Metastasis Rev 1998, 17:7-23.

39. Fukuto JM, Cisneros CJ, Kinkade RL: A comparison of the chemistry associated with the biological signaling and actions of nitroxyl (HNO) and nitric oxide (NO). J Inorg Biochem 2013, 118:201-208.

40. Ridnour LA, Thomas DD, Mancardi D, Espey MG, Miranda KM, Paolocci N Feelisch M, Fukuto J, Wink DA: The chemistry of nitrosative stress induced by nitric oxide and reactive nitrogen oxide species. Putting perspective on stressful biological situations. Biol Chem 2004, 385:1-10.

41. Toledo JC Jr, Augusto O: Connecting the chemical and biological properties of nitric oxide. Chem Res Toxicol 2012, 25:975-989.

42. Thomas DD, Ridnour LA, Isenberg JS, Flores-Santana W, Switzer CH, Donzelli S, Hussain P, Vecoli C, Paolocci N, Ambs S, Colton CA, Harris CC, Roberts DD, Wink DA: The chemical biology of nitric oxide: implications in cellular signaling. Free Radic Biol Med 2008, 45:18-31.

43. Wink DA, Miranda KM, Espey MG, Pluta RM, Hewett SJ, Colton C, Vitek M, Feelisch M, Grisham MB: Mechanisms of the antioxidant effects of nitric oxide. Antioxid Redox Signal 2001, 3:203-213.

44. Thomas DD, Ridnour LA, Espey MG, Donzelli S, Ambs S, Hussain SP, Harris CC, DeGraff W, Roberts DD, Mitchell JB, Wink DA: Superoxide fluxes limit nitric oxide-induced signaling. J Biol Chem 2006, 281:25984-25993.

45. Vitek MP, Brown C, Xu Q, Dawson H, Mitsuda N, Colton CA: Characterization of $\mathrm{NO}$ and cytokine production in immune-activated microglia and peritoneal macrophages derived from a mouse model expressing the human NOS2 gene on a mouse NOS2 knockout background. Antioxid Redox Signal 2006, 8:893-901.

46. Combet S, Balligand JL, Lameire N, Goffin E, Devuyst O: A specific method for measurement of nitric oxide synthase enzymatic activity in peritoneal biopsies. Kidney Int 2000, 57:332-338.

47. Livak KJ, Schmittgen TD: Analysis of relative gene expression data using real-time quantitative $P C R$ and the 2(-delta delta $C(T)$ ) method. Methods 2001, 25:402-408.

48. Ambs S, Glynn SA: Candidate pathways linking inducible nitric oxide synthase to a basal-like transcription pattern and tumor progression in human breast cancer. Cell Cycle 2011, 10:619-624.

49. Ambs S, Merriam WG, Ogunfusika MO, Bennett WP, Ishibe N, Hussain SP, Tzeng EE, Geller DA, Billiar TR, Harris CC: p53 and vascular endothelial growth factor regulate tumor growth of NOS2-expressing human carcinoma cells. Nat Med 1998, 4:1371-1376.

50. Liu S, Grigoryan MM, Vasilevko V, Sumbria RK, Paganini-Hill A, Cribbs DH, Fisher MJ: Comparative analysis of H\&E and prussian blue staining in a mouse model of cerebral microbleeds. J Histochem Cytochem 2014, July 25. E published ahead of print.

51. Wilcock DM, Morgan D, Gordon MN, Taylor TL, Ridnour LA, Wink DA, Colton CA: Activation of matrix metalloproteinases following anti-abeta immunotherapy; implications for microhemorrhage occurrence. J Neuroinflammation 2011, 8:115.

52. Wilcock DM, Rojiani A, Rosenthal A, Subbarao S, Freeman MJ, Gordon MN, Morgan D: Passive immunotherapy against abeta in aged APP-transgenic mice reverses cognitive deficits and depletes parenchymal amyloid deposits in spite of increased vascular amyloid and microhemorrhage. I Neuroinflammation 2004, 1:24

53. Yang Y, Estrada EY, Thompson JF, Liu W, Rosenberg GA: Matrix metalloproteinase-mediated disruption of tight junction proteins in cerebral vessels is reversed by synthetic matrix metalloproteinase inhibitor in focal ischemia in rat. J Cereb Blood Flow Metab 2007, 27:697-709.

54. Ridnour LA, Thomas DD, Switzer C, Flores-Santana W, Isenberg JS, Ambs S, Roberts DD, Wink DA: Molecular mechanisms for discrete nitric oxide levels in cancer. Nitric Oxide 2008, 19:73-76.

55. Bogdan C: Nitric oxide and the immune response. Nat Immunol 2001, 2:907-916.

56. Markesbery WR: Oxidative stress hypothesis in alzheimer's disease. Free Radic Biol Med 1997, 23:134-147.

57. Floyd RA: Antioxidants, oxidative stress, and degenerative neurological disorders. Proc Soc Exp Biol Med 1999, 222:236-245.

58. Smith MA, Nunomura A, Zhu X, Takeda A, Perry G: Metabolic, metallic, and mitotic sources of oxidative stress in alzheimer disease. Antioxid Redox Signal 2000, 2:413-420.

59. Fischer MT, Sharma R, Lim JL, Haider L, Frischer JM, Drexhage J, Mahad D, Bradl M, van Horssen J, Lassmann H: NADPH oxidase expression in active multiple sclerosis lesions in relation to oxidative tissue damage and mitochondrial injury. Brain 2012, 135:886-899.

60. Gherasim C, Yadav PK, Kabil O, Niu WN, Banerjee R: Nitrite reductase activity and inhibition of $\mathrm{H}(2) \mathrm{S}$ biogenesis by human cystathionine ss-synthase. PloS One 2014, 9:e85544.

61. Haas J, Storch-Hagenlocher B, Biessmann A, Wildemann B: Inducible nitric oxide synthase and argininosuccinate synthetase: co-induction in brain tissue of patients with alzheimer's dementia and following stimulation with beta-amyloid 1-42 in vitro. Neurosci Lett 2002, 322:121-125.

62. Malinski T: Nitric oxide and nitroxidative stress in alzheimer's disease. J Alzheimers Dis 2007, 11:207-218.

63. Rodrigo J, Fernandez-Vizarra P, Castro-Blanco S, Bentura ML, Nieto M, Gomez-Isla T, Martinez-Murillo R, Martlnez A, Serrano J, Fernandez AP: Nitric oxide in the cerebral cortex of amyloid-precursor protein (SW) Tg2576 transgenic mice. Neuroscience 2004, 128:73-89.

64. Ridnour L, Dhanapal S, Hoos M, Wilson J, Lee J, Cheng R, Brueggemann E, Hines H, Wilcock D, Vitek M, Wink DA, Colton CA: Nitric oxide-mediated regulation of beta-amyloid clearance via alterations of MMP-9/TIMP-1. J Neurochem 2012, 234:736-749.

65. Thomas DD, Espey MG, Pociask DA, Ridnour LA, Donzelli S, Wink DA Asbestos redirects nitric oxide signaling through rapid catalytic conversion to nitrite. Cancer Res 2006, 66:11600-11604.

66. Radde R, Duma C, Goedert M, Jucker M: The value of incomplete mouse models of alzheimer's disease. Eur J Nucl Med Mol Imaging 2008, 35(Suppl 1):S70-S74

67. Colton CA, Wilson JG, Everhart A, Wilcock DM, Puolivali J, Heikkinen T, Oksman J, Jaaskelainen O, Lehtimaki K, Laitinen T, Vartiainen N, Vitek MP: mNos2 deletion and human NOS2 replacement in alzheimer disease models. J Neuropathol Exp Neurol 2014, 73:752-769.

68. Fernandez-Vizarra P, Fernandez AP, Castro-Blanco S, Encinas JM, Serrano J Bentura ML, Munoz P, Martinez-Murillo R, Rodrigo J: Expression of nitric oxide system in clinically evaluated cases of alzheimer's disease. Neurobiol Dis 2004, 15:287-305

69. Braman RS, Hendrix SA: Nanogram nitrite and nitrate determination in environmental and biological materials by vanadium (III) 
reduction with chemiluminescence detection. Anal Chem 1989, 61:2715-2718.

70. Wilcock DM, Lewis MR, Van Nostrand WE, Davis J, Previti ML, Gharkholonarehe N, Vitek MP, Colton CA: Progression of amyloid pathology to alzheimer's disease pathology in an amyloid precursor protein transgenic mouse model by removal of nitric oxide synthase 2. J Neurosci 2008, 28:1537-1545.

doi:10.1186/1750-1326-9-50

Cite this article as: Hoos et al.: The impact of human and mouse

differences in NOS2 gene expression on the brain's redox and immune environment. Molecular Neurodegeneration 2014 9:50.

\section{Submit your next manuscript to BioMed Central and take full advantage of:}

- Convenient online submission

- Thorough peer review

- No space constraints or color figure charges

- Immediate publication on acceptance

- Inclusion in PubMed, CAS, Scopus and Google Scholar

- Research which is freely available for redistribution 